\title{
Taxing the People, Not Trade: the International Monetary Fund and the Structure of Taxation in Developing Countries
}

\author{
Bernhard Reinsberg $^{1,2}$ (D) Thomas Stubbs $^{1,3} \cdot$ Alexander Kentikelenis $^{4}$ \\ Published online: 8 July 2020 \\ (C) The Author(s) 2020
}

\begin{abstract}
Strengthening fiscal capacity in low- and middle-income countries is essential for achieving sustainable development. The International Monetary Fund - the world's premier agent of fiscal policy reform - has taken a front-stage role in this process, promoting a model of tax policy that favors broad-based consumption taxes and discourages trade taxes. This article investigates the links between IMF-mandated tax reforms and the evolution of tax revenues. Using novel measures of tax-related conditionality and disaggregated data on revenues, our analysis shows that IMF interventions are significantly related to changes in tax structure. In particular, IMF programs increase revenues derived from goods and services taxes, but decrease revenues collected from trade taxes. Results for personal and corporate income taxes are inconclusive. These findings have important implications for debates on the role of the IMF in developing countries.
\end{abstract}

Keywords International Monetary Fund $\cdot$ IMF programs $\cdot$ State capacity $\cdot$ Taxation $\cdot$ Tax conditionality . Value-added tax

JEL Codes F33 F F34 F53

Electronic supplementary material The online version of this article (https://doi.org/10.1007/s12116-02009307-4) contains supplementary material, which is available to authorized users.

Bernhard Reinsberg

bernhard.reinsberg@glasgow.ac.uk

1 Centre for Business Research, University of Cambridge, Cambridge, UK

2 School of Social and Political Sciences, University of Glasgow, 40 Bute Gardens, Adam Smith Building, Glasgow G12 8RT, UK

3 Royal Holloway, University of London, London, UK

4 Bocconi University, Milan, Italy 


\section{Introduction}

Strengthening fiscal capacity in low- and middle-income countries is essential for achieving sustainable development (Di John 2006; Brautigam et al. 2008; Besley and Persson 2011). It enables countries to undertake necessary investments into infrastructure and national public goods, thereby increasing economic efficiency, while also strengthening the social contract with their tax-paying citizens, thus mitigating corruption and increasing political stability (Bräutigam and Knack 2004; Di John 2006; Djankov et al. 2008; Fjeldstad and Moore 2008). Consequently, it should come as no surprise that the international community - in the form of the Sustainable Development Goals - declared its ambition to strengthen fiscal capacity (SDG 17.1). In 2010, G20 leaders underscored the importance of building tax capabilities, calling for international financial institutions to ramp up their efforts.

The International Monetary Fund (IMF) - the primary global agent of fiscal policy reform-has taken a front-stage role in this process. Through its in-house tax research (e.g., Keen 2009; Cottarelli 2011; Akitoby et al. 2018), the institution disseminates experience on tax policy reforms across its 189 member countries. For instance, by providing technical assistance in the form of the Tax Policy Assessment Framework (TPAF), the IMF supports country efforts to redesign their tax systems. The IMF can also compel tax policy reforms in its role as a "lender of last resort," where countries in economic trouble adopt structural reforms in exchange for emergency loans (Stone 2002). The IMF has used its uniquely powerful position to promote a model of tax policy that favors broad-based consumption taxes and discourages trade taxes (Seabrooke 2010; Ban 2015, 2016; Kentikelenis and Seabrooke 2017; Stubbs and Kentikelenis 2018a).

A sympathetic viewpoint on the IMF's policy advice is that the organization offers a hub of expertise on tax issues that helps build the capacity of weak states by conducting research and disseminating best practices (Tanzi and Zee 2001; Akitoby et al. 2018). In this role, the IMF has prioritized assistance to developing countries for revenue mobilization through its surveillance, lending, and technical assistance (Cottarelli 2011). Its fiscal policy experts have advised on measures aimed at raising revenues and establishing more effective tax administrations (Fjeldstad and Moore 2008, 242-43).

For its critics, the IMF promotes "neoliberal policies" that undermine state institutions (Kentikelenis and Babb 2018; Kentikelenis and Babb 2019; Reinsberg et al. 2019a; Reinsberg et al. 2019b). They claim that Fund policy prescriptions-despite well-advertised modifications in recent years-still have a market-oriented thrust (Grabel 2011; Güven 2012; Ban and Gallagher 2015), entailing privatization of public enterprises, imposition of user fees, and a shift away from supposedly "progressive" forms of taxes toward "regressive" value-added taxes (VAT) (Kentikelenis et al. 2016). IMF tax advice, they argue, typically follows standard prescriptions that privilege business interests-notably, the introduction of broad-based VAT with no exemptions - which may not be the appropriate tax recipe for all countries under all circumstances (Emran and Stiglitz 2005; Bird and Gendron 2007; Stiglitz 2009; Stewart 2016).

In light of this debate, we revisit the relationship between IMF programs and tax revenues using a panel of up to 119 developing countries over the 1993-2013 period. We use data for four types of tax revenues available from the International Centre for 
Tax and Development (Prichard et al. 2014), along with computer-assisted coding of text from newly available IMF conditionality data (Kentikelenis et al. 2016). We find that IMF programs rebalance the composition of tax revenues from trade taxes to goods and services taxes, but do not increase the overall tax intake. Controlling for nonrandom selection and a host of confounders, IMF programs are associated with an increase in goods and services tax revenue by more than $2 \%$ of the GDP in the long run, but a decrease in trade tax revenue that is smaller in magnitude in most models. Further analyses show that IMF interventions increase the likelihood of VAT introduction, and that the IMF's impact on goods and services revenue is greatest when the IMF explicitly mandates policy measures on this tax.

Our findings contribute to an important debate in development policy. We offer novel insights for scholars and practitioners focusing on the fiscal impact of economic reform programs designed by international financial institutions (IFIs). Until now, this strand of research has primarily focused on the IMF's impact on public spending (e.g., Nooruddin and Simmons 2006; Clements et al. 2013; Rickard and Caraway 2018), paying less attention to its impact on revenues. Although our findings are consistent with earlier studies on revenues of a more limited scope (Mahon 2004; Crivelli 2013; Fairfield 2013; Bastiaens and Rudra 2016), we extend this work by offering a more fine-grained perspective on the impact of IMF programs. In particular, we provide disaggregated analysis into different tax types and IMF tax policy conditions that allows us to demonstrate how powerful IFIs like the IMF can shape domestic tax policies.

\section{Tax Policy and the International Monetary Fund}

Social scientists have long scrutinized the macro-historical determinants of tax policy (Mann 1986; Tilly 1990; Aidt and Jensen 2009; D’Arcy and Nistotskaya 2017), andin more recent years - the role of globalization has received growing attention (Wibbels and Arce 2003; Dietsch and Rixen 2016; Swank 2016). Among the global determinants shaping tax policy, the IMF — with its broad membership and unchallenged role as global lender of last resort - has been among the most influential actors (Babb 2013; Stone 2002; Woods 2006). The organization offers financial support to countries in economic trouble in exchange for far-ranging policy reforms, collectively known as "conditionality." In relation to taxation, the IMF is interested in raising tax revenues as a means to stabilize countries in fiscal difficulties, but also seeks to promote privatesector activity through lower taxes, especially for businesses (Tanzi and Zee 2001; IMF 2017a).

The IMF's policy advice covers four types of taxes. First, the organization considers trade taxes to be distortive, especially when they impose uneven customs duties that are intended to benefit domestic industries, while purportedly harming unorganized groups like consumers (Tait 1989, p. 7). Eliminating trade taxes is also consistent with the overall goal of promoting trade liberalization (Woods 2006). Second, the IMF has advised against more personal income taxes, noting that such taxes distort economic choices (IMF 2017a, p. 47). In developing countries, income taxes contribute little to overall tax revenue, given that the number of individuals subject to this tax is small (Tanzi and Zee 2001). In the IMF's view, developing countries manage income taxes 
poorly because of too many expense deduction possibilities, especially in the higher brackets (Tait 1989, p. 6). In recent years, the IMF has come to support progressive income taxes to improve the distribution of income (IMF 2017a, p. 6), but only in advanced economies (IMF 2017b, p. 28). Third, the IMF discourages corporate income taxes due to purported implications on business competitiveness. Its corporate tax policy advice is geared toward supply-side tax reductions, removal of tax exemptions, and general rate equalization (Tait 1989, p. 7). For example, in a recent World Economic Outlook, the IMF applauds Colombia for introducing an "investment-friendly tax reform" (IMF 2017b, p. 17). IMF economists have also advocated unification of multiple corporate tax rates, which they claim distort economic activities across different sectors (Tanzi and Zee 2001). Finally, the IMF has long viewed goods and services taxes - specifically the VAT - as holding significant promise to boost fiscal revenue. As an indirect tax, the IMF considers the VAT to be an attractive choice for governments because its implementation is relatively easy compared to income taxes, and its design makes tax fraud less likely. The benefits of a VAT are said to be best achieved under a broad base, a low rate applicable to all products, and few exemptions (Tanzi and Zee 2001). For example, the IMF welcomes the nationwide introduction of the goods and services tax in India in July 2017, as it "promises unification of India's vast domestic market ... and [to] push growth above 8 per cent in the medium term" (IMF 2017b, p. 17).

Unsurprisingly, such far-ranging tax policy advice has significant fiscal ramifications. Raising consumption taxes can increase fiscal revenues, while reductions to trade, income, and corporate taxes may have the opposite effect, notwithstanding improvements to investment and administrative efficiency. As Tanzi and Zee (2001) write, "[d]eveloping countries will need to reduce sharply their reliance on foreign trade taxes, without at the same time creating economic disincentives, especially in raising more revenue from personal income tax." The IMF thus places a premium on "efficient" taxes, bolstered by its own research for OECD countries showing that the VAT increases revenues while offsetting revenue losses from other taxes (Keen and Lockwood 2006). However, the IMF has offered fewer pronouncements on the distributional consequences of efficient taxes. Where discussed, their distributional consequences are understood as potentially adverse, but compensable from the expenditure side of the fiscal balance with-for example - social safeguards targeted at the most vulnerable households (Tait 1989; Fjeldstad and Moore 2008; Genschel and Seelkopf 2016).

How can the IMF affect tax policy choices in its member countries? In general, policy change occurs through three different mechanisms: competition, learning, and coercion (Dobbin et al. 2007). First, as an organization tasked with reviewing macroeconomic policies of its member states, the IMF promotes dissemination of "best practices" (Kelley and Simmons 2015). In the context of competitive regulatory pressures, IMF surveillance accelerates the adoption of "best practices" across countries - for instance by improving information and thereby amplifying market pressure toward adoption of market-friendly policies (Lombardi and Woods 2008). Second, the IMF provides technical assistance at the request of member states, which accelerates adoption of certain economic policies due to higher exposure to policy ideas by policymakers (Seabrooke and Nilsson 2015). A number of studies highlight the importance of technical assistance and spread of ideas through macroeconomic 
research in purveying tax policies (Keen and Lockwood 2010; Mabugu and Simbanegavi 2015). Third, the IMF exerts greatest leverage over its member countries when they require IMF assistance - for instance, due to dire economic circumstancesthrough conditionality.

While governments still have leeway in implementing conditionality, the IMF can compel far-reaching policy reform in its member countries because access to credit is contingent on commitment to such reforms (Vreeland 2007). Hence, countries should be more likely to adopt IMF-favored tax policy when they need capital infusions (Swank 2016). Our research design-discussed below-allows us to test explicitly for the impact of IMF tax conditionality versus other mechanisms of IMF influence.

In light of this discussion, we hypothesize that IMF programs - especially those including tax conditionality-will change the tax structure in developing countries: those participating in IMF programs will increase VAT revenue but reduce revenues from trade, corporate, and income taxes. Case-based evidence of such IMF-induced changes in tax structures is indicative. For example, in 1998, the government of Rwanda turned to the IMF to access a USD 95 million loan in exchange for its promise to reform its administration and eventually adopt VAT in 2001 (IMF 1999). In a follow-up program commencing in 2002, the Fund then called on the government to increase the VAT rate from 15 to $17 \%$, while-at the same time - mandating a reduction in corporate income tax rates from 40 to $35 \%$ (IMF 2002). While the IMF's policy advice substituted one type of tax for another, it failed to engineer a substantive increase in overall tax revenues in Rwanda (Prichard et al. 2014), as was the underlying motivation. We will test below whether Rwanda's experience with IMF-mandated tax reforms holds more generally in the developing world.

\section{Empirical Evidence on IMF Programs and Tax Revenues}

A voluminous body of literature focuses on the impact of IMF programs on the overall fiscal balance (Bulír and Moon 2004) and, in particular, the spending side of the budget (Nooruddin and Vreeland 2010; Hamm et al. 2012; Stubbs et al. 2017a; Stubbs et al. 2017b). These studies mostly conclude that participation in IMF programs improves fiscal outcomes (Dreher and Vaubel 2004; Easterly 2005; Atoyan and Conway 2006). But only limited research has considered the revenue side, most of it conducted by IMF staff. Bulír and Moon (2004) study fiscal outcomes in a short panel of 112 countries in the mid-1990s. They find that although most countries improved their fiscal balance, they took different strategies depending on their relationship with the Fund. Countries without IMF programs reduced expenditures but maintained revenue, while countries with IMF programs reduced both. In the latter countries, conditionality did not have a significant impact on fiscal positions. Mahon (2004) studied the determinants of tax reform in Latin America, finding that the IMF catalyzed VAT introduction in many countries, but that its conditionality had no significant impact among democracies. Using pooled ordinary least squares on 15 countries over 19771995, his analysis includes two binary variables - an IMF program indicator and a measure of tax conditionality-which allows for untangling the impact of tax 
conditionality from other aspects of IMF assistance. Studying the 1984-2007 period, Brun et al. (2011) conclude that IMF programs had a negative impact on total revenues in sub-Saharan Africa. In contrast, IMF programs increased tax revenue when countries had high levels of institutional quality, as measured by bureaucratic quality and the absence of corruption. This is consistent with Bird and Gendron (2007, p. 181), who argue that "unfortunately, many countriesincluding most in sub-Saharan Africa-began their 'modern' tax systems with an unpromising legacy of state-private relations, with almost no trained officials, and in a very difficult political and economic setting." Keen and Lockwood (2010) corroborate the pessimistic picture for sub-Saharan Africa, establishing that IMF program participation boosts tax revenue only outside that world region.

Scholars argue that in many countries, the demise of trade taxes following trade liberalization - a strategy pursued by governments often at the behest of the IFIshas not been matched by equivalent increases in goods and services taxes (Mansour and Keen 2009; Keen and Lockwood 2010; Bastiaens and Rudra 2016; Genschel and Seelkopf 2016). To test this possibility, Bastiaens and Rudra (2016) regress three types of non-trade tax revenue on trade tax revenue (as proxy for trade liberalization), IFI assistance for tax systems, and an interaction effect for different regime types. In a sample of developing countries from 1990 to 2009, they find evidence for a positive impact of IFI assistance on domestic taxes in non-democracies after trade liberalization. Their research design differs from ours in two key aspects. First, motivated by their specific research question, they treat trade taxes as exogenous, thus neglecting the possibility that IFI assistance itself can modify such tax revenue. Another potential problem is that IFI assistance is unlikely to be exogenous. Second, their measure of IFI assistance is not comparable to the one used in other studies (including ours) because it uses technical assistance rather than lending, while also neglecting policy conditions, which is a possible source of omitted variable bias.

While these studies have improved our understanding of the links between IMF programs and tax revenues, they suffer from several drawbacks. First, many studies have limited regional scope, typically focusing on a particular region, for example, post-Soviet economies (Crivelli 2013), Latin America (Mahon 2004; Fairfield 2013), or OECD countries (Keen and Lockwood 2006). Second, studies face methodological challenges relating to short panels, pooling of observations, endogeneity bias, and use of non-transparent system-GMM estimation. A recent IMF staff paper, examining the determinants of 55 episodes of sustained tax increases, selects on positive cases only, thus limiting its inference (Akitoby et al. 2018). Third, studies generally do not spend sufficient efforts to capture heterogeneity within IMF programs. While some studies consider variation within IMF programs due to specific types of conditionality (Mahon 2004), they lack systematic analysis of the implications of tax conditionality on tax structures. Finally, as most studies are authored by IMF staff, our study provides an external view on the issues at hand. Indeed, Clist (2016) reports doubtful methodological choices, poor data quality, and lack of documentation, which prevented successful replication of published research on tax revenues. Similar criticisms have also been leveled against IMF studies covering the expenditure side of the fiscal balance (Stubbs and Kentikelenis 2018b). 


\section{Data and Methods}

\section{Tax Data}

For our empirical analysis, we exploit newly available datasets on tax revenue, tax adoption, and IMF conditionality. Our sample includes non-high-income countries, tantamount to GDP per capita below 12,736 US\$ according to the World Bank definition, observed from 1993 to 2013. The choice of sample period primarily reflects concerns with data availability. In particular, tax data disaggregated by different taxes are available for more than 100 countries only for this time period. It also avoids the structural break due to the breakdown of the Soviet Union, thus ensuring measurement equivalence over a twenty-year horizon (Keen and Lockwood 2010).

Tax data comes from the Global Revenue Dataset (GRD) collected by the International Centre for Tax and Development (ICTD). The ICTD GRD data combine several sources to generate extensive time-series cross-section revenue data (Prichard et al. 2014). We use the following variables from the ICTD GRD data as dependent variables: total tax revenue, goods and services tax revenue, (personal) income tax revenue, and corporate (income) tax revenue. In the multivariate analysis, all variables are expressed as percentage of GDP. ${ }^{1}$

Using the tax revenue data, we first assess graphically the effect of IMF programs on the composition of tax revenue (Fig. 1). We split the sample into two groups: countries that never had an IMF program (left panel) and countries that had at least one IMF program (right panel). The evolution of tax structures differs markedly across the two groups. Since the end of the Cold War, countries under IMF exposure increased the share of revenues from goods and services tax relative to trade tax. No clear pattern emerges for countries without IMF programs. Moreover, there is no apparent difference in the evolution of relative revenues between both groups for corporate taxes and income taxes. Overall, the patterns provide a first indication that IMF exposure leads countries to adjust the relative importance of different tax types.

\section{Conditionality Data}

To scrutinize the impact of specific tax policy conditions, we use a new dataset on conditionality agreed between the Fund and its borrowing countries over more than three decades (Kentikelenis et al. 2016). As this database includes the text of policy conditions, we are able to identify conditions related to taxation using computerassisted text matching. We construct several indicators. First, any tax condition covers all tax-related conditions, which include measures related to tax revenues, tax structure, and capacity building of tax administrations. About one fourth of IMF programs include at least one such condition. Second, we further distinguish two types of tax conditionality, specifically on goods and services, and trade, respectively. We do not

\footnotetext{
${ }^{1}$ While some researchers use log-transformed tax revenues as dependent variable (Clist and Morrissey 2011; Morrissey et al. 2014; Morrissey and Torrance 2015), we follow others using untransformed tax revenues for ease of interpretation (Besley and Persson 2008; Baunsgaard and Keen 2010; Cárdenas and Tuzemen 2011; Crivelli 2013; Prichard 2014). Log-transformation is not necessary in our case because diagnostic plots do not indicate problems with skewness in the revenue variables. Regardless, our results are not sensitive to this transformation.
} 


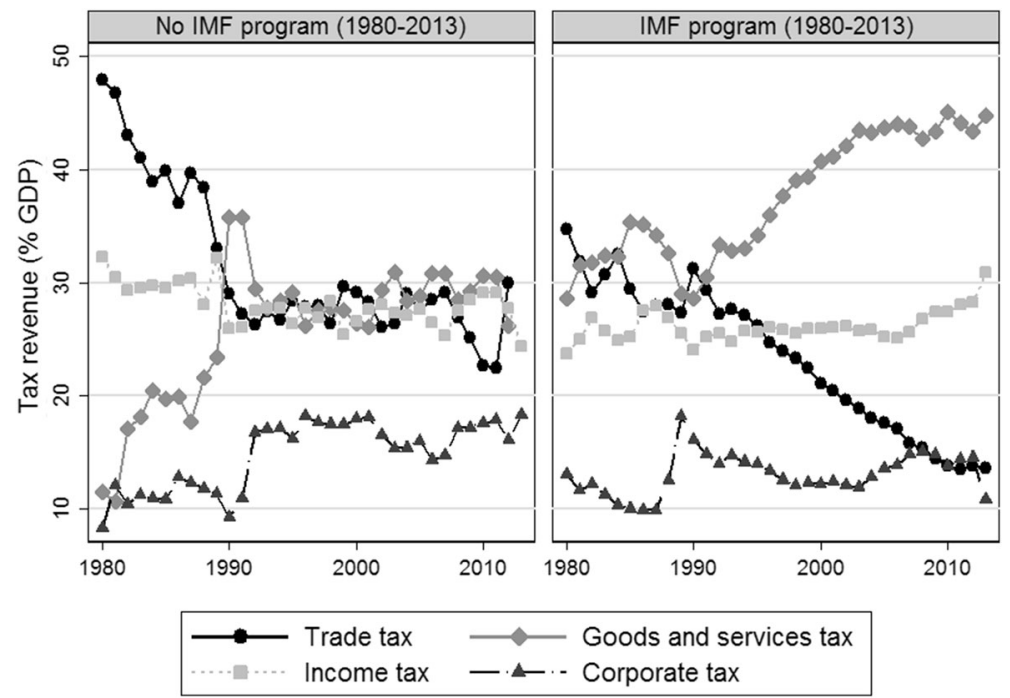

Fig. 1 Evolution of tax revenues by IMF exposure. Data sources: IMF conditionality database (Kentikelenis et al. 2016) and ICTD GRD tax data (Prichard et al. 2014). Based on 110 IMF program countries and 31 nonIMF program countries

attempt to further analyze the content of these conditions to avoid introducing coding bias. Reforms require specific taxes to be altered in specific ways, for example, introducing a tax, altering its modalities, or abolishing it. For country-year-level analysis, we create a dichotomous variable indicating the presence of a given tax condition. This discards information on the number of conditions but does not assume that each tax condition is equally important. Tax conditions are rather rare, so a dichotomous measure is more robust than a continuous one. ${ }^{2}$ The supplemental appendix details the coding procedure for these measures.

Based on the IMF conditionality dataset, we graphically trace the evolution of tax conditionality (Fig. 2). Its inclusion in IMF programs spread rapidly-from near zero in 1980 to $40 \%$ in 1989 . The incidence of tax conditionality peaked in 2000 , when it was included in about $75 \%$ of IMF programs. Such conditions have remained common since, although the nature of tax conditionality has shifted away from specific taxes toward more comprehensive reforms in tax systems and administration.

\section{Control Variables}

We include a number of time-varying control variables from the literature on taxation (Aidt and Jensen 2009; Baunsgaard and Keen 2010; Clist and Morrissey 2011; Prichard 2016). Most of these variables capture the tax base of a country. For example, we include the natural logarithm of GDP per capita because richer countries have more taxable income and are better able to collect taxes from their citizens (Scheve and Stasavage 2010; Clist and Morrissey 2011; Morrissey and Torrance 2015). We also include non-tax revenue (as a percentage of GDP) — available from the ICTD GRD

\footnotetext{
${ }^{2}$ We do not separate binding conditions from non-binding conditions because the low frequency of tax conditions would prevent model convergence.
} 


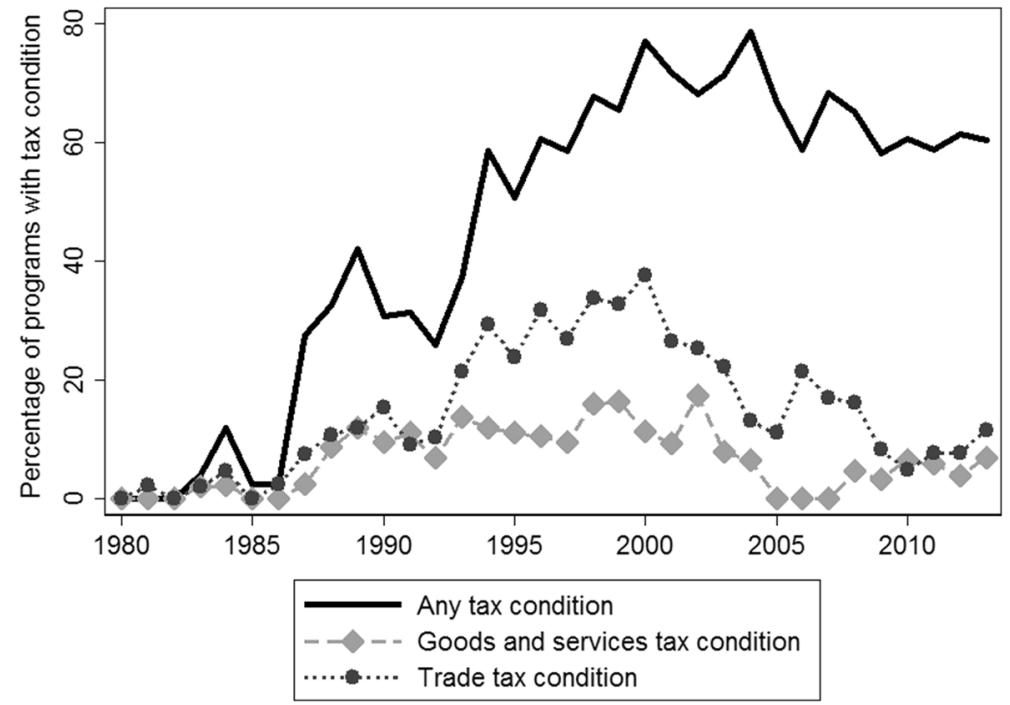

Fig. 2 The use of tax conditionality in IMF programs over time. Data sources: Own coding based on the IMF conditionality database (Kentikelenis et al. 2016)

data - to capture the lower revenue requirements in countries with alternative income sources (Prichard 2014). Trade openness (as a percentage of GDP) is included because trade taxes are relatively easy to collect (Clist and Morrissey 2011). In contrast, tax collection from the agricultural sector is difficult in developing countries because agriculture is primarily a subsistence activity, so we include agricultural output as a percentage of GDP. Finally, we include the percentage rate of GDP growth, expecting a positive relationship since booms in the business cycle should facilitate tax revenue generation (Prichard 2014). Unless otherwise stated, we source all control variables from the World Development Indicators (World Bank 2015). We also include countryfixed effects that capture time-invariant determinants of tax revenue such as history of warfare, years of democratic experience, income inequality, and natural resource endowments (Besley and Persson 2011; Cárdenas and Tuzemen 2011; Morrissey and Torrance 2015). In addition, we include year-fixed effects to capture global factors that affect tax revenues equally in all countries. Table 1 shows descriptive statistics for all variables in our main analysis. ${ }^{3}$

\section{Model Specification}

We use a statistical model (ad hoc) to test the relationship between IMF interventions and the structure of taxation in developing countries. Following recent advice, we proceed with a general model and test restrictions to identify the appropriate statistical model (Keele and Kelly 2006; De Boef and Keele 2008; Beck and Katz 2011). In particular, our models include a lagged dependent variable, which is warranted theoretically because governments often target revenues based on realized revenue of the previous fiscal year. The econometric rationale for including the lagged dependent

\footnotetext{
${ }^{3}$ Table A1 in the Supplemental Appendix shows detailed data sources.
} 
Table 1 Descriptive statistics of main variables

\begin{tabular}{|c|c|c|c|c|c|}
\hline & Observations & Mean & Standard deviation & Minimum & Maximum \\
\hline Total tax revenue & 2506 & 14.6 & 6.9 & 0.3 & 62.8 \\
\hline Goods and services tax revenue & 2201 & 6.4 & 4.1 & 0.0 & 29.1 \\
\hline Trade tax revenue & 2204 & 3.5 & 4.0 & 0.0 & 42.1 \\
\hline Income tax revenue & 2122 & 4.4 & 2.8 & 0.0 & 17.1 \\
\hline Corporate tax revenue & 1570 & 2.3 & 1.7 & 0.0 & 11.5 \\
\hline IMF program & 2882 & 0.4 & 0.5 & 0.0 & 1.0 \\
\hline Any tax condition & 2882 & 0.3 & 0.4 & 0.0 & 1.0 \\
\hline Goods and services tax condition & 2882 & 0.0 & 0.2 & 0.0 & 1.0 \\
\hline Trade tax condition & 2882 & 0.1 & 0.3 & 0.0 & 1.0 \\
\hline Log(GDP per capita) & 2730 & 7.2 & 1.1 & 4.2 & 9.6 \\
\hline Total non-tax revenue & 2404 & 6.2 & 8.3 & -24.4 & 71.7 \\
\hline Trade openness & 2630 & 81.1 & 39.0 & 0.0 & 321.6 \\
\hline Agricultural output & 2568 & 20.1 & 13.4 & 1.9 & 65.9 \\
\hline GDP growth & 2745 & 4.1 & 6.6 & -62.1 & 106.3 \\
\hline Past programs & 2961 & 2.4 & 2.5 & 0.0 & 6.0 \\
\hline Countries under programs & 2961 & 62.0 & 8.6 & 41.0 & 75.0 \\
\hline UNGA vote alignment & 2704 & 0.6 & 0.1 & 0.3 & 1.0 \\
\hline Reserves & 2159 & 4.6 & 4.7 & 0.0 & 79.2 \\
\hline External balance & 2630 & -11.3 & 20.8 & -184.7 & 45.3 \\
\hline Debt service & 2388 & 4.5 & 5.7 & 0.0 & 135.4 \\
\hline Freedom House index & 2811 & 6.0 & 3.6 & 0.0 & 12.0 \\
\hline Executive election & 2437 & 0.1 & 0.3 & 0.0 & 1.0 \\
\hline Country office & 2961 & 0.5 & 0.5 & 0.0 & 1.0 \\
\hline Regional office & 2961 & 0.4 & 0.5 & 0.0 & 1.0 \\
\hline
\end{tabular}

Notes: Descriptive statistics for the sample period used in the main analysis (1993-2013)

variable is to mitigate serial error correlation beyond the computation of clustered standard errors (Beck and Katz 2011). Following our theoretical interest to establish short-term effects of IMF conditions on tax revenues, we include explanatory variables with lags respectively from one year up to three years. ${ }^{4}$

Another important issue pertains to the simultaneity of different kinds of tax revenues. Governments may conceive different tax types as potential substitutes toward meeting a fixed total revenue target. Tax policy choices thus are likely to be interdependent. We account for this by estimating seemingly unrelated regressions (SUR), which first estimates all constitutive equations individually before imposing a joint error structure across all equations (Roodman 2012).

\footnotetext{
${ }^{4} \mathrm{We}$ are aware that inclusion of a lagged dependent variable in the presence of fixed effects produces biased estimates (Nickell 1981) _ even though the bias is concentrated in the lagged dependent variable coefficient. In our multiple-equation setup, we cannot use the bias-corrected Anderson-Hsiao estimator for unbalanced dynamic panel data (Bruno 2005). Nonetheless, in regressions for individual tax revenues, we verified that all coefficients are similar compared to a conventional (biased) estimator.
} 
A well-known inferential challenge is non-random assignment of countries to IMF programs (Nooruddin and Simmons 2006). For instance, countries with low revenue may need to request IMF credit, thereby introducing a reverse causality problem. We therefore add a selection equation to the above SUR system, deploying well-established instruments to predict IMF program participation. Our main instrument is the UNGA Vote Alignment (Bailey et al. 2015) between the borrower and the G7 countries. The instrument is relevant because allies of big powers receive favorable treatment by IFIs (Thacker 1999; Bas and Stone 2014; Dreher et al. 2015); it is excludable because geopolitical alignment is unrelated to tax revenues conditional on control variables (such as level of development) and time-invariant country characteristics. Further improving the predictive power of our selection model, we include past programs, a count variable for the prior years of IMF exposure over a five-year horizon, previously found to reliably predict current participation (Moser and Sturm 2011). Program participation is also affected by the extent to which the Fund has resources available, which depends on the current number of program countries (Vreeland 2003). Hence, we include the contemporaneous count variable countries under programs. Additional variables capture macroeconomic conditions - logged GDP per capita, GDP growth, reserves in months of imports, EXTERNAL BALANCE (as percentage of GDP), and debt service (as percentage of GNI) - as well as political characteristics - democracy as measured by the (rescaled) Freedom House index combining political rights and civil liberties and Executive elections - that have been previously found to affect program participation. ${ }^{5}$ We also include regional dummies and year dummies.

Another challenge is that tax conditionality within IMF program countries may not be randomly assigned. For example, countries with low revenue may be particularly likely to obtain such conditions. ${ }^{6}$ We remedy this challenge by estimating an additional selection model for tax conditionality, although this time no instruments are readily available from previous literature. Our preferred instrument is a time-varying dummy variable of country eligibility for technical assistance under the regional training centers jointly managed by the Fund and its borrowers. For example, the Vienna Joint Institute is the oldest of these centers, established in 1992, while the Africa Training Institute is the most recent one, starting operations in 2013. The centers provide advice on tax administration, fiscal issues, and monetary policy. This instrument is relevant because IMF staff should be more likely to assign tax conditionality if the country would be eligible to benefit from related technical advice to implement it - given that the IMF staff are interested in the success of their programs. In the absence of a regional center, the country might not have the capacity to properly implement tax reform, even if facing a condition to do so. While our instrument may not be entirely excludable with respect to tax revenue - tax-related technical assistance might help directly raise tax revenues - we note that we use eligibility for such assistance, not whether assistance was provided, which attenuates this problem. The remaining bias likely overestimates our results, given that we expect tax-related technical assistance to increase tax

\footnotetext{
5 These variables are all lagged one period further than the lag of IMF program.

${ }^{6}$ To examine this issue further, we attempted to predict tax conditionality using tax revenue and a range of standard controls as explanatory variables, finding such conditions have similar determinants as IMF programs more generally — such as national income, economic growth, and foreign reserves - as well as lagged tax revenue $(p<0.1)$. This suggests that there is some degree of reverse causality: countries receive tax conditions due to poor revenue performance.
} 
revenues. We thus consider this approach a useful point of departure. To increase the predictive fit, we add dummies for whether a country is under an IMF program (as a necessary condition for tax conditionality), whether a country hosts an IMF Resident Representative Office (Mayer and Mourmouras 2008, p. 118), ${ }^{7}$ control variables from the outcome stage capturing the structure of the economy, and year dummies.

Together with the outcome equations, the two selection equations are part of a multiequation system with four linear equations for the respective kinds of tax revenues and two probit-type equations for IMF programs and tax conditionality, which can be consistently estimated through maximum likelihood assuming a joint multivariate normal error distribution (Roodman 2012). Country-clustered standard errors are computed to take temporal dependence of the within-country observations into account.

\section{Findings}

We expect that IMF programs alter the tax structure of borrowing countries. Using multivariate analysis, we corroborate this argument below by showing that IMF interventions increase revenue from goods and services tax while decreasing revenue from other types of tax. ${ }^{8}$

\section{Overall effect of IMF programs on tax revenues}

Table 2 shows coefficient estimates of IMF programs with respect to the different tax revenues across a three-year time horizon. Overall, IMF programs are positively related to an increase in goods and service tax revenue by $0.7 \%$ of GDP $(p<0.01)$ after one year. In substantive terms, this effect is around one tenth of the standard deviation of goods and services tax revenue. Given the dynamic model specification, the long-term effect of IMF intervention is even greater, at more than $2 \%$ of GDP. ${ }^{9}$ Effect magnitudes are smaller for subsequent lags and statistically significant only for the third lag. We do not find significant effects of IMF programs on other tax revenues.

Using Wald tests (presented in Appendix Table B1), we compare coefficients across types of tax revenue. We find that the once-lagged positively significant IMF program coefficient in goods and services tax revenue is significantly greater than its counterparts in all other tax revenues, except for income tax. The same result holds for the

\footnotetext{
${ }^{7}$ If the IMF operates a country office, it is thought to be better able to help countries build support for sound policies, and IMF resident representatives are well-placed to assist through seminars, meetings with parliamentarians, interest groups, and the media (Mayer and Mourmouras 2008, p. 118). As the Fund is interested in conditions being implemented, and tax reforms require a sustained effort to do so, then it may make sense to assign tax conditions in those countries that have a country office.

${ }^{8}$ In the supplemental appendix, we examine the determinants of the introduction of specific taxes, notably the VAT, as a necessary condition for related revenue increases. Using data from the Tax Introduction Database (Seelkopf and Lierse 2014), we find that countries that were under at least one IMF program over the past three decades have a much faster rate of adoption compared to non-IMF borrowers, while the adoption rate for other tax types is not significantly different across these two groups (Figure D1). Bivariate probit regressions show that IMF programs significantly increase the probability of VAT adoption until three years into an IMF program (Table D1).

9 The long-term effect can be computed as $\beta /(1-\alpha)=2.03$, where $\alpha$ is the coefficient on the lagged dependent variable and $\beta$ the short-term coefficient. We use the bias-corrected estimate $(\alpha=0.7)$.
} 


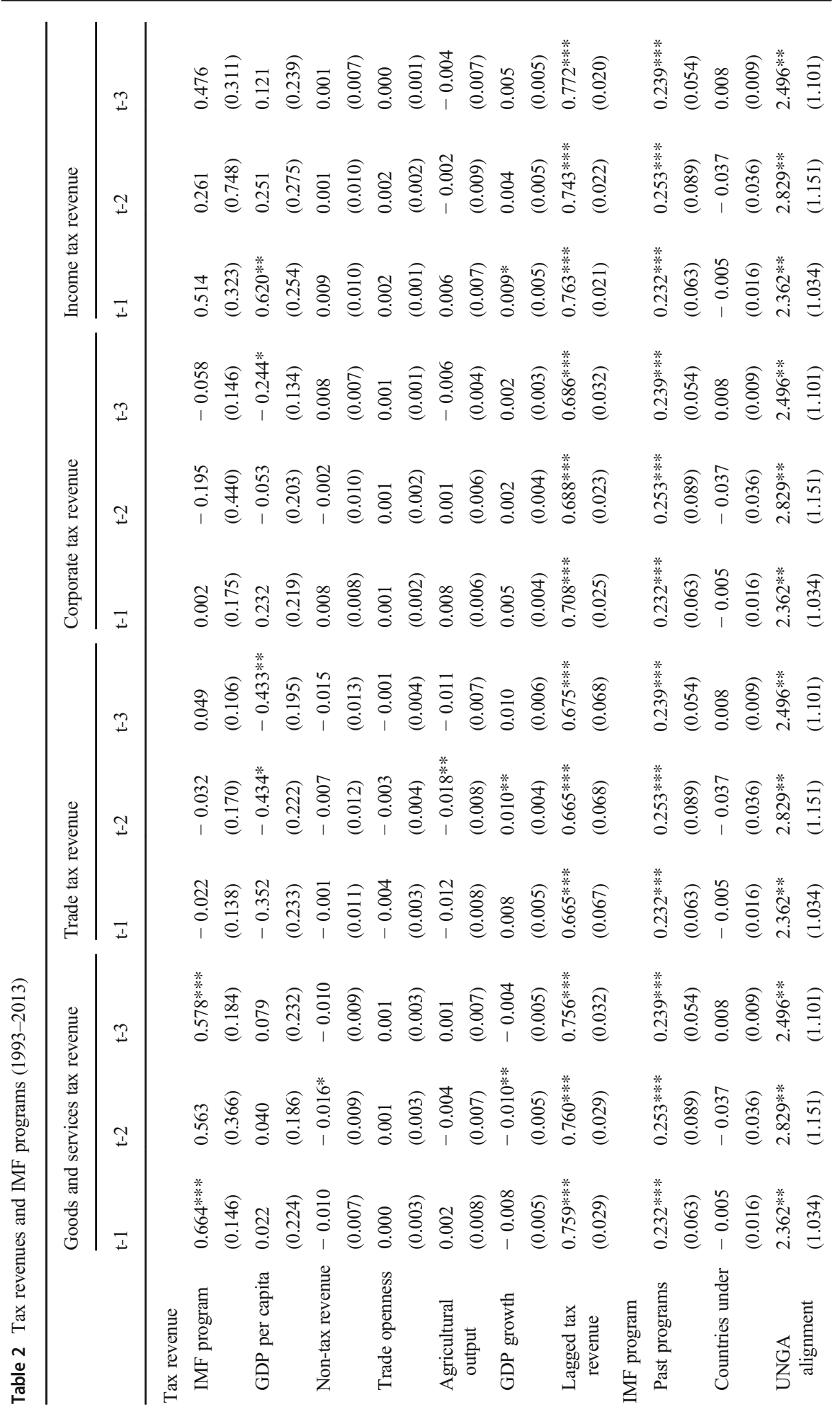




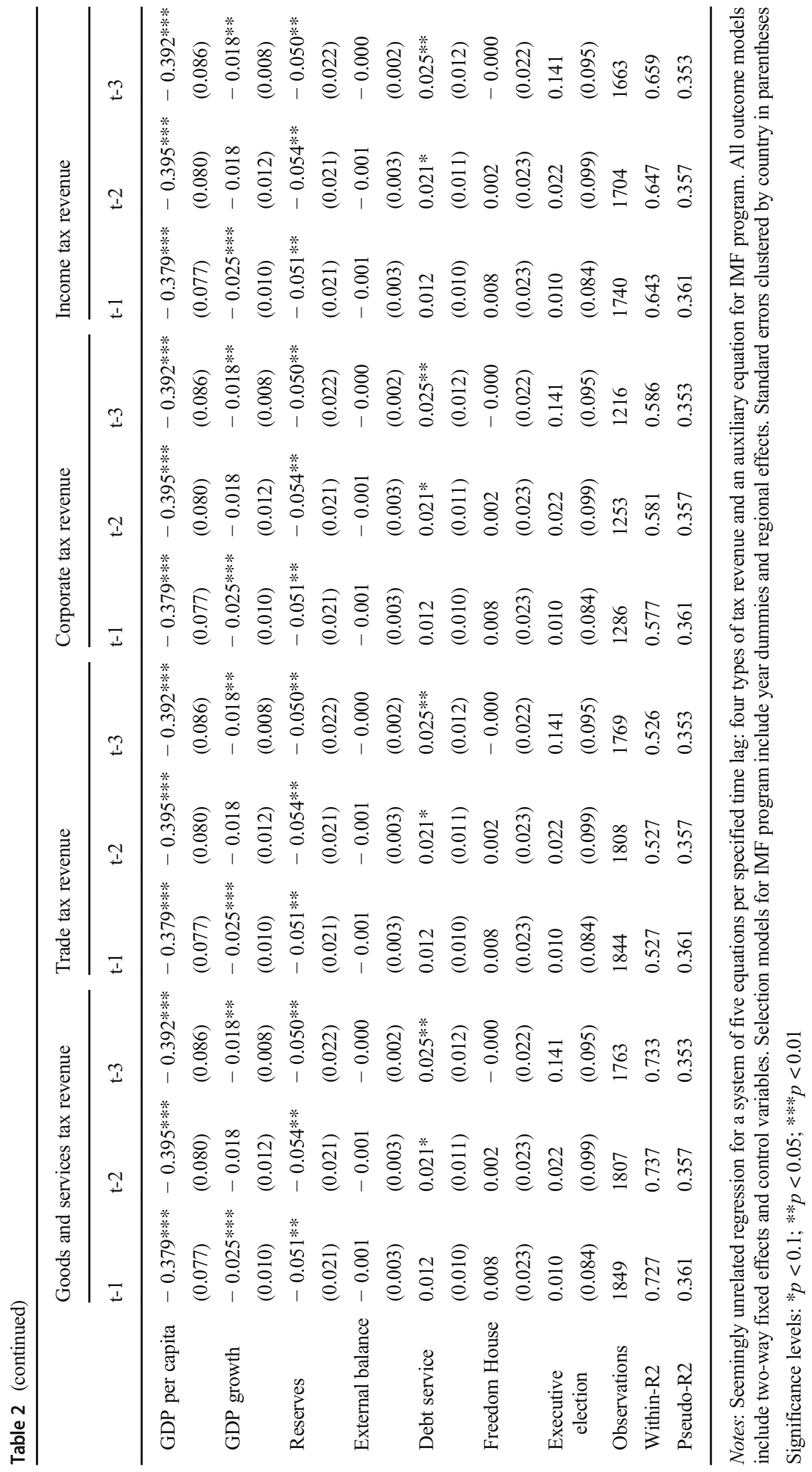


second-lagged IMF program coefficient. Two significant differences remain: the difference in once-lagged coefficients in trade tax revenue and income tax revenue, and the difference in third-lagged coefficients in corporate tax revenue and income tax revenue. Wald tests can also determine whether IMF assistance succeeds in recouping lost revenue from certain tax types by other tax types (Appendix Table B2). To that end, we test whether the sum of any two coefficients is different from zero, finding that the IMF-induced growth in goods and service tax revenue over-compensates for the loss in trade tax revenue. We find no significant compensation effects for other combinations of tax revenues.

Table 2 also includes coefficients of all control variables and the selection equation. Control variables typically do not reach standard thresholds of statistical significance but, where they do, exhibit their expected effect direction. For example, richer countries are relatively more reliant on personal income taxes. Overall, our models explain around $70 \%$ of the within-country variation, indicating that they feature important variables capturing the relevant tax bases. Turning to the selection model, we corroborate the pertinent results of previous research establishing the importance of borrower recidivism, economic fundamentals, and geopolitical factors. Highly significant economic predictors of IMF programs include per-capita income, GDP growth, foreign reserves, and debt service. Moreover, we find evidence that countries voting in line with the major powers in the UN General Assembly are more likely to obtain IMF loans, while domestic politics (specifically the Freedom House index and executive elections) are not statistically significant.

\section{The Effect of Tax Conditionality on Tax Revenues}

We now assess the impact of specific types of tax conditions. Table 3 proceeds with a test of whether any kind of tax conditionality affects tax revenues within a three-year horizon. Results indicate that tax conditionality is positively related to goods and services tax revenue in the first year. Among all IMF programs, goods and services tax revenue is higher by about $0.81 \%$ of GDP for those with tax conditionality than those without it $(p<0.05)$. Since our estimations include a lagged dependent variable, the cumulative effect of this instantaneous increase is $3.24 \%$ of GDP, or $80 \%$ of a standard deviation in tax revenue. The coefficient of IMF programs remains positive but becomes statistically insignificant, suggesting that tax conditionality drives the change in tax revenue. In the second year, however, tax conditionality exerts a weakly negative effective on goods and services tax revenue $(p<0.1)$, while other aspects of the program exert no effect. In the third year, both tax conditionality and other aspects of IMF programs significantly increase goods and services tax revenue, although both effects are smaller than before and less precisely estimated.

Next, we find that tax conditionality significantly reduces trade tax revenue by $0.93 \%$ of GDP after one year $(p<0.01)$, which translates into a cumulative effect of $2.79 \%$ of GDP, representing more than $70 \%$ of a standard deviation of trade tax revenue. This negative effect is somewhat mitigated by a positively significant IMF program effect of about $0.54 \%$ of GDP $(p<0.05)$, or $1.61 \%$ of GDP in cumulative terms. This effect may be related to the receipt of fresh loans, technical assistance, or signaling effects. 


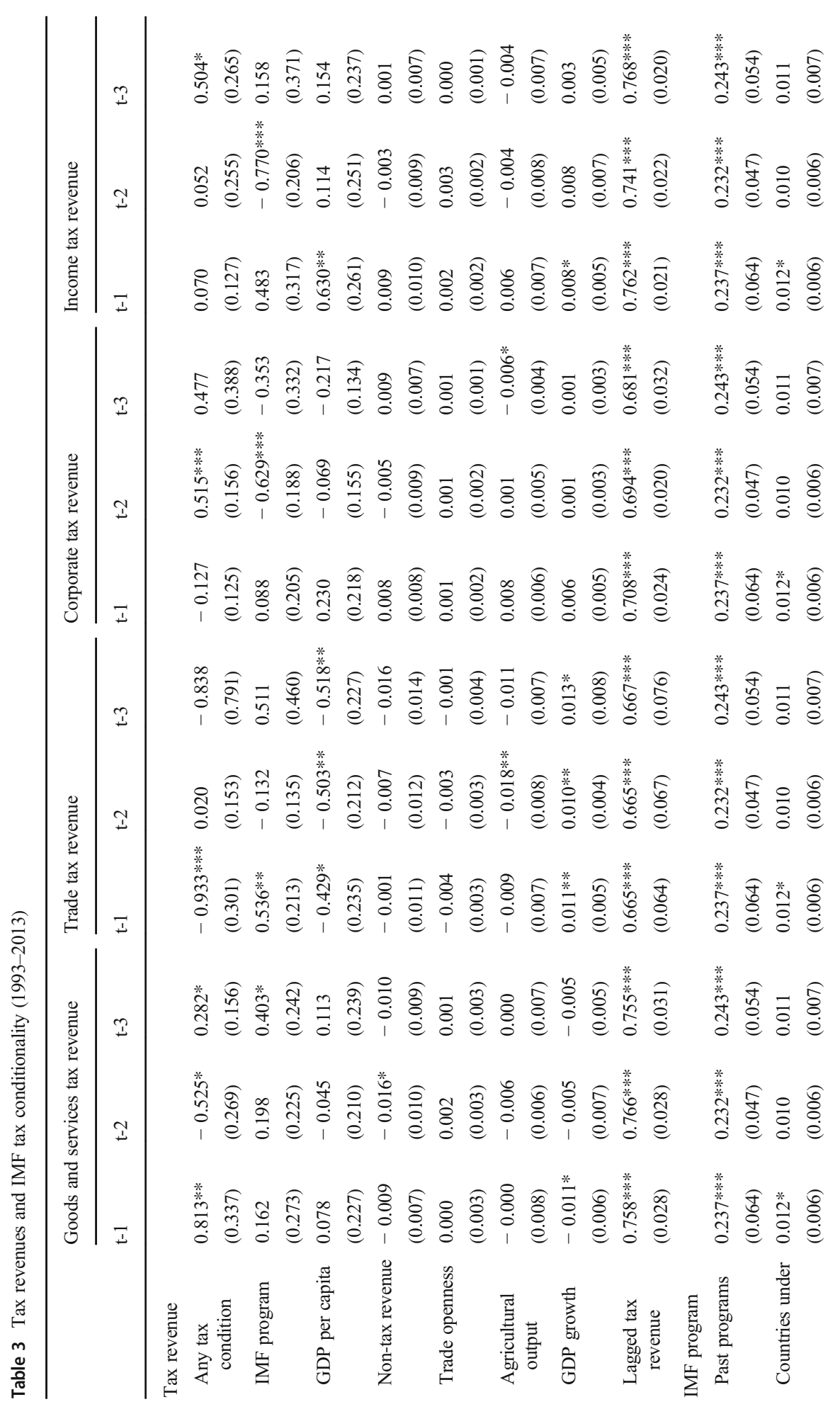




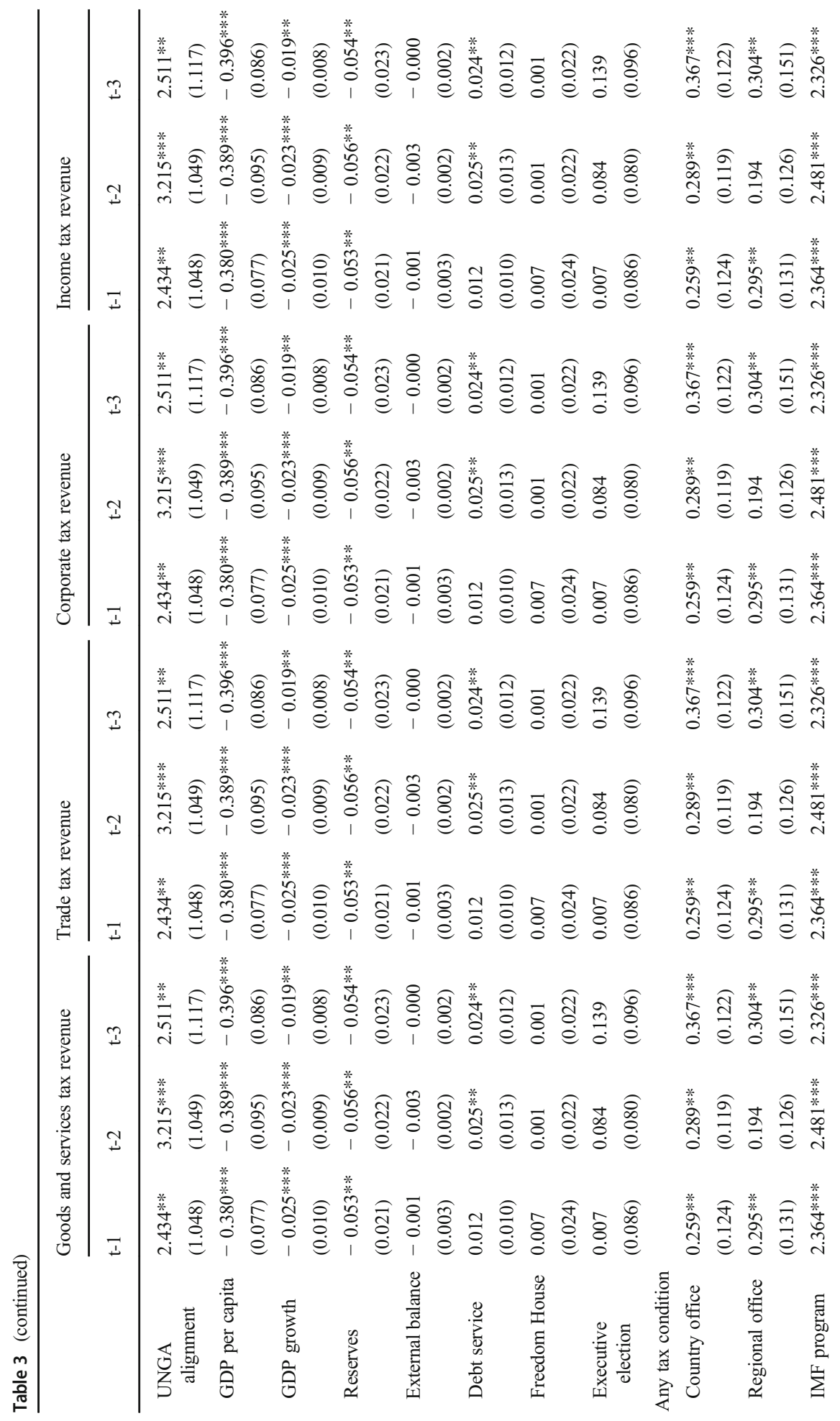




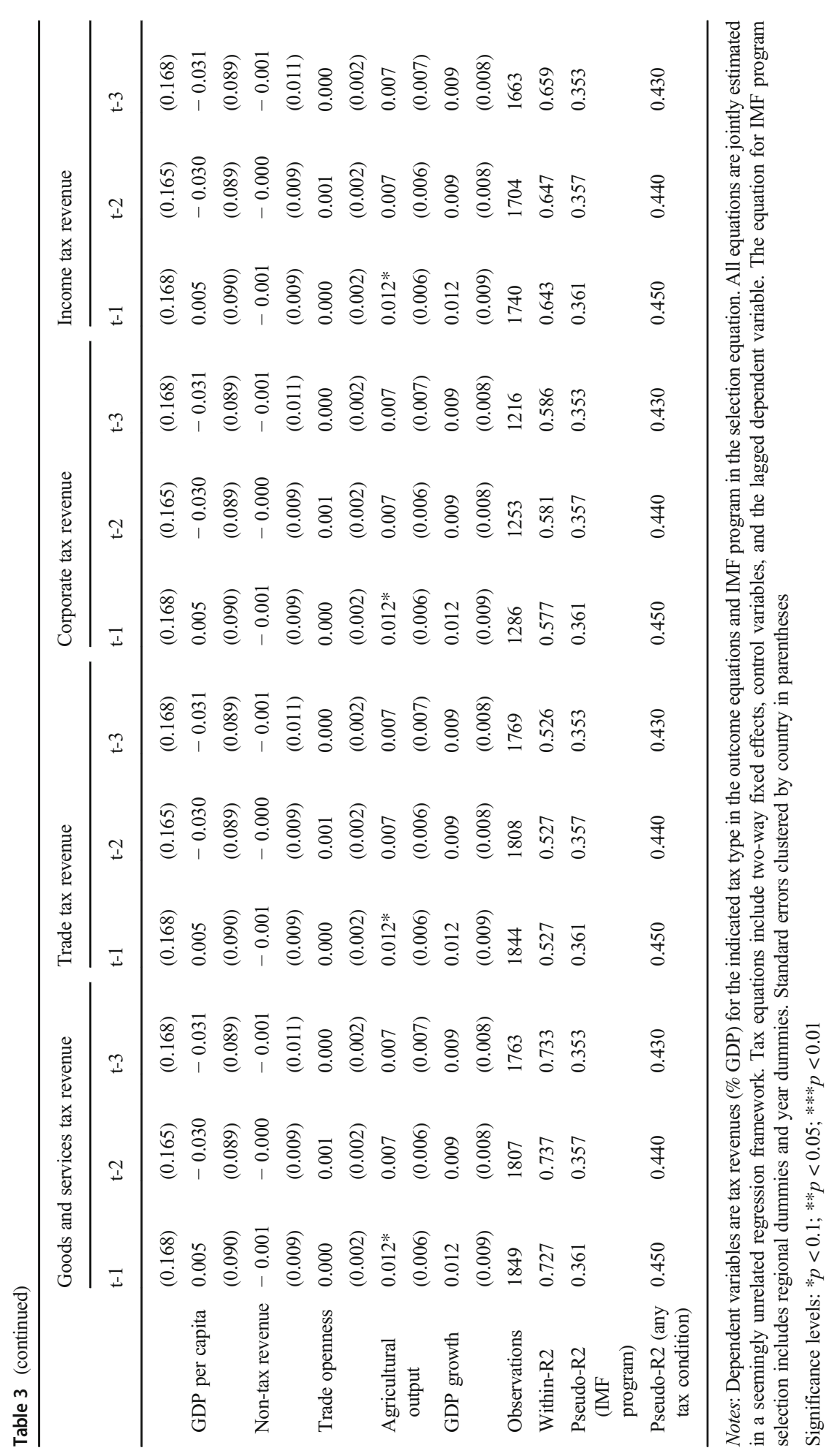


Turning to the remaining types of tax revenues, we find that tax conditionality is associated with increased corporate tax revenue after two years $(p<0.01)$, but the overall effect of IMF intervention is negative, given the substantially larger point estimate for residual aspects of IMF programs $(p<0.01)$. We also obtain a significantly negative effect of IMF programs on income tax revenue after two years, although tax conditionality tends to reverse this effect after three years $(p<0.1)$. The negative coefficients of the IMF program dummy-diverging from the coefficients of tax conditionality - are entirely plausible as they may indicate the adverse revenue implications of market-liberalizing policy reforms that are often attached to IMF lending programs.

We now compare coefficients on tax conditionality across equations using Wald tests (presented in Appendix Table B3). Considering just the differences in once-lagged coefficients, we find that the effect of any tax condition is significantly larger in goods and services tax revenues than in all other tax revenues, while being significantly smaller in trade tax revenue compared to all remaining tax revenues, at least at the 5\% level. Conversely, none of the IMF program coefficient differences for the first lag are significant across equations. Findings for subsequent lags are less consistent, suggesting that the divergence in tax revenue types due to tax conditionality is strongest in the first year.

Our coding protocol further allows us to identify tax conditions that only pertain to specific types of tax revenues. Table 4 relates two specific types of tax revenue to the two respective types of tax conditions, notably for goods and services taxes, and trade taxes. ${ }^{10}$ We find that conditionality related to goods and services taxes - notably VAT measures - robustly increases the associated tax revenue in the first year. Substantively, such conditions increase VAT revenue instantaneously by $1.07 \%$ of GDP, and $4.29 \%$ of GDP in the long term $(p<0.01)$. Residual aspects of IMF programs exert weakly positive effects. The reverse image emerges for trade tax conditionality. Trade taxrelated conditionality reduces trade tax revenue by at most $0.97 \%$ of GDP in the first year, or $2.89 \%$ of GDP in the long term $(p<0.01)$. Effects in subsequent years remain statistically significant but are somewhat smaller.

In sum, to the extent that our research design lends itself to causal interpretation of coefficient estimates, our results show that IMF tax conditionality has played an essential role in trimming trade taxes and boosting goods and services tax revenue, while helping secure increases in corporate tax and income tax revenues (Table 5).

\section{Robustness Checks}

We probe the robustness of our main findings in the supplemental appendix. First, we verify that our results hold under an alternative instrument for tax conditionality (Table C1). To predict tax conditionality in a given program, we use the number of IMF programs in the same region with tax conditionality in the same year. This instrument is relevant to the degree that it picks up fads in IMF program design, such as the design of tax conditionality (Stubbs et al. 2020). More importantly, the instrument is plausibly excludable because tax conditionality in other programs is unlikely to

\footnotetext{
${ }^{10}$ There are not enough observations on corporate tax and income tax for our structural estimations to converge with the respective tax conditionalities.
} 
Table 4 Tax revenues and IMF tax conditionality on specific tax types (1993-2013)

\begin{tabular}{|c|c|c|c|c|c|c|}
\hline & \multicolumn{3}{|c|}{$\begin{array}{l}\text { Goods and services tax } \\
\text { revenue }\end{array}$} & \multicolumn{3}{|c|}{ Trade tax revenue } \\
\hline & $\mathrm{t}-1$ & $\mathrm{t}-2$ & $\mathrm{t}-3$ & $\mathrm{t}-1$ & $\mathrm{t}-2$ & $\mathrm{t}-3$ \\
\hline \multirow[t]{2}{*}{ Tax conditionality } & $1.072 * * *$ & 0.220 & 0.236 & $-0.965 * *$ & $-0.691^{*}$ & $-0.761 * *$ \\
\hline & $(0.338)$ & $(0.161)$ & $(0.162)$ & $(0.426)$ & $(0.407)$ & $(0.375)$ \\
\hline \multirow[t]{2}{*}{ IMF program } & $0.521 *$ & $0.336^{*}$ & $0.435^{* *}$ & 0.181 & 0.122 & 0.085 \\
\hline & $(0.284)$ & $(0.178)$ & $(0.220)$ & $(0.126)$ & $(0.137)$ & $(0.107)$ \\
\hline Control variables & Yes & Yes & Yes & Yes & Yes & Yes \\
\hline Selection equation for IMF program & Yes & Yes & Yes & Yes & Yes & Yes \\
\hline Selection equation for tax conditionality & Yes & Yes & Yes & Yes & Yes & Yes \\
\hline Observations & 1849 & 1807 & 1763 & 1844 & 1808 & 1769 \\
\hline Within-R2 & 0.727 & 0.738 & 0.734 & 0.527 & 0.527 & 0.526 \\
\hline Pseudo-R2 (IMF program) & 0.361 & 0.357 & 0.353 & 0.361 & 0.357 & 0.353 \\
\hline Pseudo-R2 (Tax conditionality) & 0.450 & 0.440 & 0.430 & 0.450 & 0.440 & 0.430 \\
\hline
\end{tabular}

Notes: Tax conditionality refers to any tax condition specifically on the revenue type shown in the column header. Dependent variables are tax revenues (\% GDP) for the indicated tax type in the outcome equation. In a given panel - corresponding to a specific type of revenue - equations are jointly estimated in a seemingly unrelated regression framework. Tax equations include two-way fixed effects, control variables, and the lagged dependent variable. The equation for IMF program selection includes regional dummies and year dummies. The tax conditionality equation uses country office, regional office, IMF program, and control variables from the outcome equation as predictors. Standard errors clustered by country in parentheses

Significance levels: $* p<0.1 ; * * p<0.05 ; * * *<0.01$

affect tax revenues in a given country, except through the diffusion of such conditionality. Using this alternative instrument, we find that tax conditionality robustly increases goods and services tax revenue but reduces trade tax revenue in the first year $(p<0.01)^{11}$

Second, another strategy to remedy potential endogeneity is to use internal instruments and estimate system GMM regressions (Roodman 2009). This approach is often considered to be problematic - as it lacks transparency and rests on assumptions that are unlikely to hold in the context of IMF program effects research (Stubbs et al. 2020) - but it is useful when external instruments for tax conditionality are hard to find. We estimate a system GMM model with a once-lagged IMF program indicator, instrumented by second lags of all variables from the selection model in the differences equation and first difference of these variables in the levels equation. When we split programs into those with tax conditionality and those without - assuming they can be both instrumented with the same variables - we find that IMF programs with tax conditionality increase revenue from goods and services taxes but exert no effect on other revenue types (Table C2). Overall, this analysis is consistent with our findings.

Finally, albeit not our main focus of analysis, we also scrutinize an extended sample period. While data are available for the 1980-2013 period, we preferred the 1993-2013

\footnotetext{
${ }^{11}$ We limit the presentation of our findings to the first lag of the effect due to space constraints. Results for later lags are similar to the main results.
} 
Table 5 Overview of main results

\begin{tabular}{|c|c|c|c|c|}
\hline $\begin{array}{l}\text { Dependent } \\
\text { variable(s) }\end{array}$ & $\begin{array}{l}\text { Key } \\
\text { predictor(s) }\end{array}$ & Correction for endogeneity & Main finding & Source \\
\hline \multirow{3}{*}{$\begin{array}{l}\text { Tax revenues } \\
\text { - Goods and } \\
\text { services } \\
\text { - Trade } \\
\text { - Corporate } \\
\text { income } \\
\text { - Personal } \\
\text { income }\end{array}$} & IMF program & $\begin{array}{l}\text { Selection model for IMF } \\
\text { program (using UN General } \\
\text { Assembly vote alignment as } \\
\text { exogenous predictor) }\end{array}$ & $\begin{array}{l}\text { IMF program increases goods } \\
\text { and services tax revenues } \\
(p<0.01) \text { except after } \\
2 \text { years }\end{array}$ & Table 2 \\
\hline & $\begin{array}{l}\text { - Any tax } \\
\text { condition- } \\
\text { ality } \\
\text { - IMF } \\
\text { program } \\
\text { (capturing } \\
\text { residual } \\
\text { aspects) }\end{array}$ & $\begin{array}{l}\text { - Selection model for IMF } \\
\text { program (as above) } \\
\text { - Selection model for any tax } \\
\text { conditionality (using } \\
\text { existence of IMF regional } \\
\text { center as exogenous } \\
\text { predictor } \\
\text { As before but } \\
\text { - Alternative instrument using } \\
\text { number of programs with } \\
\text { tax conditionality in the } \\
\text { region }\end{array}$ & $\begin{array}{l}\text { - Any tax conditionality } \\
\text { increases goods and } \\
\text { services tax revenues in first } \\
\text { year }(p<0.05) \text { and third } \\
\text { year }(p<0.1) \text { but reduces in } \\
\text { second year }(p<0.1) \text {; } \\
\text { reduces trade tax revenue in } \\
\text { first year }(p<0.01) ; \\
\text { increases corporate tax } \\
\text { revenue in second year } \\
(p<0.01) \text { and income tax } \\
\text { revenue in third year } \\
(p<0.1) \\
\text { - Residual effect of IMF } \\
\text { intervention positive for } \\
\text { goods and services tax } \\
(p<0.1) \text { and trade tax } \\
(p<0.05) \text { but negative for } \\
\text { corporate tax and income } \\
\text { tax }(p<0.01) \\
\text { Any tax conditionality now } \\
\text { unrelated to income tax } \\
\text { revenue; reduces trade tax } \\
\text { revenue also in third year } \\
\text { ( } p<0.05) \text {; no effect on } \\
\text { goods and services tax in } \\
\text { third year }\end{array}$ & $\begin{array}{l}\text { Table } 3 \\
\text { Table C1 }\end{array}$ \\
\hline & $\begin{array}{l}\text { - Tax } \\
\text { condition- } \\
\text { ality on } \\
\text { goods and } \\
\text { services tax } \\
\text { - Tax } \\
\text { condition- } \\
\text { ality on } \\
\text { trade tax }\end{array}$ & $\begin{array}{l}\text { - Selection model for IMF } \\
\text { program (as above) } \\
\text { - Selection model for any tax } \\
\text { conditionality (using } \\
\text { existence of IMF regional } \\
\text { center as exogenous } \\
\text { predictor) }\end{array}$ & $\begin{array}{l}\text { - Tax conditionality on goods } \\
\text { and services tax increases } \\
\text { goods and services tax } \\
\text { revenue in first year } \\
(p<0.01) \text {, with positive } \\
\text { residual effect of IMF } \\
\text { intervention throughout } \\
(p<0.1) \\
\text { - Tax conditionality on trade } \\
\text { tax decreases trade tax } \\
\text { revenue throughout } \\
\text { ( } p<0.05, \text { except } p<0.1 \text { in } \\
\text { second year); no residual } \\
\text { effect of IMF program }\end{array}$ & Table 4 \\
\hline
\end{tabular}

period for consistency with previous research (Crivelli and Gupta 2016). And yet, the main results are robust in the 1980-2013 period. Considering the aggregate effect of IMF programs on tax revenues (Table C3), we find an even stronger positive relationship between IMF programs and goods and service tax revenues $(p<0.01)$; an 
insignificant relationship between IMF programs and trade tax revenue; and a positive relationship between IMF programs and income tax revenue. Considering tax conditions and respective types of tax revenue (Table $\mathrm{C} 4$ ), we find a positively robust (shortterm) effect of tax conditionality on goods and services tax revenue, as well as a negatively robust effect of tax conditionality on trade tax revenue. This again demonstrates that tax conditionality has effectively altered tax structures in developing countries over the past 35 years.

\section{Conclusion}

In recent years, IFIs have declared the strengthening of fiscal capacity of developing countries to be a key priority (IMF 2016). Yet, the IMF is not impartial in its tax policy advice. The VAT, applied with a broad base, uniform rates, and no exemptions, is favored, while trade taxes and taxes with distortive effects are discouraged. We hypothesized that IMF tax policy preferences alter the composition of tax revenues in developing countries, particularly when these countries are susceptible to IMF policy pressure via conditional lending programs. Indeed, we found that the average program is associated with increases in goods and services tax revenue and decreases in trade tax revenue. We also found that tax conditions attached to these programs matter for delivering the aforementioned changes to tax systems. Tax conditionality has less consistent effects on other tax revenues, though these effects tend to be positive. Our main result thus is that IMF tax conditionality alters the composition of tax revenues, holding across different specifications of selection models, estimation methods, and sample periods.

Our findings contribute to political economy research examining the role of IFIs in national economic policy-making. In particular, although earlier findings of IMFinduced under-recovery of lost trade tax revenue are not disputed (Seelkopf, Lierse, and Schmitt 2016), these rest on specific model choices. Our SUR analysis, which considers all relevant tax types as jointly determined, fails to provide robust evidence for under-recovery, but rather suggests that the loss in trade tax revenue is compensated by VAT revenue. As a result, IMF tax conditionality serves to alter the structure of taxation in developing countries.

The structure of taxation has important socio-economic implications for borrowing countries, and the IMF's emphasis on the introduction of VAT and maximization of its revenues can be controversial. To be sure, many economists argue that the VAT is well-designed to implement fundamental principles of optimal taxation theory: there should be no taxation of capital, no taxation of intermediary goods, and low top rates for income taxes (Diamond and Mirrlees 1971; Mankiw et al. 2009; Mirrlees 2011). By averting distortion of production decisions, the VAT is said to maximize economic efficiency. Meanwhile, the objective of redistribution, according to optimal taxation theory, is best pursued through other mechanisms such as lump-sum transfers. However, development economists point out that while a tax system with heavy reliance on VAT may be optimal for advanced economies, it is inappropriate for many developing countries (Emran and Stiglitz 2005; Bird and Gendron 2007; Stewart 2016). First, it may have adverse distributive impact, as the set of instruments for redistribution is more limited in developing countries. Second, it may be less conducive to economic 
efficiency, because the presence of a non-taxable informal sector distorts allocation decisions. Indeed, when a large part of the economy is informal, the VAT is not applied universally, but a trade tax may be. Third, the VAT is less corruption-resistant given that record-keeping systems are not well-advanced in developing countries (Stiglitz 2009). Future research can explore these issues.

Our findings open several further avenues for subsequent work. For one, we encourage analysis of country heterogeneity in the relationship between IMF tax conditionality and tax revenues. For instance, our current research design does not allow for explicit tests of whether capacity affects the efficacy of tax policy advice. Another important task for future research is to assess the welfare implications of IMFinduced changes to the tax structure. In principle, countries may expect welfare gains to the extent that they adopt more efficient taxes - such as the VAT — even though such taxes may be regressive and thus increase the need for redistribute measures (Bräutigam 2008; Stiglitz 2009; Genschel and Seelkopf 2016). Future analysis thus must simultaneously examine the efficiency and equity effects of different taxes. In doing so, it needs to consider short-term effects and long-term effects, while at the same time finding convincing solutions to the challenge of endogeneity, for instance due to reverse causality.

Although our analysis focuses on the 1993-2013 period, its conclusions are timely. In recent years, the IMF has begun to consider the equity implications of its interventions. Prominent figures in the institution assert that the IMF has shifted away from "Washington Consensus"-style policies (Ostry et al. 2016). In relation to tax policy, its Tax Policy Assessment Framework (TPAF) now entails a more balanced assessment of the VAT, noting that it is a relatively efficient revenue-raising instrument but that it is also perceived to be regressive. Despite such rhetorical concessions, several studies suggest that IMF practices have hardly changed (Gabor 2010; Güven 2012; Vernengo and Ford 2014; Kentikelenis et al. 2016), and that they continue to have a negative impact on inequality (Forster et al. 2019). A glance at a recent edition of the Fiscal Monitor confirms that the IMF's current tax policy advice is consistent with its traditional emphasis on austerity: it calls for "growth-friendly fiscal policies," such as "improving the design of tax policies [to help] remove the distortions that are holding more productive firms back" (IMF 2017a). To meet the SDG target for strengthening fiscal capacity and to avoid inequality-increasing forms of taxation, the IMF needs to reconsider the appropriateness of its tax policy advice toward developing countries.

Acknowledgments We would like to thank Toke Aidt, Lawrence Broz, Jonas Bunte, Peter Harris, and Elena McLean for helpful comments.

Open Access This article is licensed under a Creative Commons Attribution 4.0 International License, which permits use, sharing, adaptation, distribution and reproduction in any medium or format, as long as you give appropriate credit to the original author(s) and the source, provide a link to the Creative Commons licence, and indicate if changes were made. The images or other third party material in this article are included in the article's Creative Commons licence, unless indicated otherwise in a credit line to the material. If material is not included in the article's Creative Commons licence and your intended use is not permitted by statutory regulation or exceeds the permitted use, you will need to obtain permission directly from the copyright holder. To view a copy of this licence, visit http://creativecommons.org/licenses/by/4.0/. 


\section{References}

Aidt TS, Jensen PS. The taxman tools up: an event history study of the introduction of the personal income tax. J Public Econ Elsevier BV. 2009;93(1-2):160-75.

Akitoby B et al. (2018) Tax revenue mobilization episodes in emerging markets and low-income countries: lessons from a new dataset, IMF working papers \#234. Washington D.C.

Atoyan R, Conway P. Evaluating the impact of IMF programs: a comparison of matching and instrumentalvariable estimators. Rev Int Organ. 2006;1(2):99-124.

Babb SL. The Washington consensus as transnational policy paradigm: its origins, trajectory and likely successor. Rev Int Polit Econ. 2013;20(2):268-97.

Bailey MA, Strezhnev A, Voeten E. Estimating dynamic state Preferences from United Nations voting data. J Confl Resolut. 2015;61(2):430-56.

Ban C. From designers to doctrinaires: staff research and fiscal policy change at the IMF. In: Morgan G, Hirsch P, Quack S, editors. Elites on Trial: Research in the Sociology of Organizations: Emerald Group Publishing Limited; 2015. p. 337-69.

Ban C. Ruling ideas: how global neoliberalism goes local. Oxford: Oxford University Press; 2016.

Ban C, Gallagher KP. Recalibrating policy orthodoxy: the IMF since the great recession. Governance. 2015;28(2):131-46.

Bas MA, Stone RW. Adverse selection and growth under IMF programs. Rev Int Organ. 2014;9(1):1-28.

Bastiaens I, Rudra N. Trade liberalization and the challenges of revenue mobilization: can international financial institutions make a difference? Rev Int Polit Econ. 2016;23(2):261-89.

Baunsgaard T, Keen M. Tax revenue and (or?) trade liberalization. J Public Econ. 2010;94(9-10):563-77.

Beck NL, Katz JN. Modeling dynamics in political economy data. Annu Rev Polit Sci. 2011;14:331-52.

Besley T, Persson T. Wars and state capacity. J Eur Econ Assoc. 2008;6(2/3):522-30.

Besley T, Persson T. Fiscal capacity. In: Pillars of prosperity: the political economics of development clusters; 2011. p. 41-102.

Bird RM, Gendron P-P. The VAT in developing and transitional countries, the VAT in developing and transitional countries. Cambridge: Cambridge University Press; 2007.

De Boef S, Keele L. Taking time seriously. Am J Polit Sci. 2008;52(1):184-200.

Bräutigam DA. Introduction: taxation and state-building in developing countries. In: Taxation and statebuilding in developing countries; 2008. p. 1-33.

Brautigam DA, Fjeldstad OH, Moore M. Taxation and state-building in developing countries. Cambridge: Cambridge University Press; 2008.

Bräutigam DA, Knack S. Foreign aid, institutions, and governance in sub-Saharan Africa. Econ Dev Cult Chang. 2004;52(2):255-85.

Brun JF, Chambas G, Laporte B (2011) IMF programs and tax effort What role for institutions in Africa. CERDI working paper \#33.

Bruno GSF. Estimation and inference in dynamic unbalanced panel-data models with a small number of individuals. Stata J. 2005;5(4):473-500.

Bulír A, Moon S. Is fiscal adjustment more durable when the IMF is involved? Comp Econ Stud. 2004;46(3): 373-99.

Cárdenas M, Tuzemen D (2011) Under-investment in state capacity: the role of inequality and political instability, Federal Reserve Bank of Kansas City, research working paper 11-07.

Clements B, Gupta S, Nozaki M. What happens to social spending in IMF-supported programmes? Appl Econ. 2013;45(28):4022-33.

Clist P. Foreign aid and domestic taxation: multiple sources, one conclusion. Dev Policy Rev. 2016;34(3): 365-83.

Clist P, Morrissey O. Aid and tax revenue: signs of a positive effect since the 1980s. J Int Dev. 2011;23:16580 .

Cottarelli C. Revenue mobilization in developing countries. In: International Monetary Fund; 2011. Available at: http:/www.imf.org/external/np/pp/eng/\%0A2011/030811.pdf.

Crivelli E. Fiscal impact of privatization revisited: the role of tax revenues in transition economies. Econ Syst. 2013;37(2):217-32.

Crivelli E, Gupta S. Does conditionality in IMF-supported programs promote revenue reform? Int Tax Public Financ. 2016;23(3):550-79.

D’Arcy M, Nistotskaya M. State first, then democracy: using cadastral records to explain governmental performance in public goods provision. Governance. 2017;30(2):193-209. 
Diamond PA, Mirrlees J. Optimal taxation and public production II: tax rules. Am Econ Rev. 1971;61(3):26178.

Dietsch P, Rixen T. Global tax governance: what it is and why it matters. In: Global tax governance: what is wrong with it and how to fix it; 2016. p. 1-23.

Djankov S, Montalvo JG, Reynal-Querol M. The curse of aid. J Econ Growth. 2008;13(3):169-94.

Dobbin F, Simmons BA, Garrett G. The global diffusion of public policies: social construction, coercion, competition, or learning? Annu Rev Sociol. 2007;33(1):449-72.

Dreher A, Sturm J-E, Vreeland JR. Politics and IMF conditionality. J Confl Resolut. 2015;59(1):120-48.

Dreher A, Vaubel R. The causes and consequences of IMF conditionality. Emerg Mark Financ Trade. 2004;40(3):26-54.

Easterly W. What did structural adjustment adjust?: the association of policies and growth with repeated IMF and World Bank adjustment loans. J Dev Econ. 2005;76(1):1-22.

Emran MS, Stiglitz JE. On selective indirect tax reform in developing countries. J Public Econ. 2005;89(4): 599-623.

Fairfield T. Going where the money is: strategies for taxing economic elites in unequal democracies. World Dev. 2013;47:42-57.

Fjeldstad $\mathrm{OH}$, Moore M. Tax reform and state-building in a globalised world. In: Taxation and state-building in developing countries; 2008. p. 235-60.

Forster T, Kentikelenis AE, Reinsberg B, Stubbs TH, King LP. How structural adjustment programs affect inequality: a disaggregated analysis of IMF conditionality, 1980-2014. Soc Sci Res. 2019;80:83-113.

Gabor D. The International Monetary Fund and its new economics. Dev Chang. 2010;41(5):805-30.

Genschel P, Seelkopf L. Did they learn to tax? Taxation trends outside the OECD. Rev Int Polit Econ. 2016;23(2):316-44.

Grabel I. Not your grandfather's IMF: global crisis, productive incoherence, and developmental policy space. Camb J Econ. 2011;35(5):805-30.

Güven AB. The IMF, the World Bank, and the global economic crisis: exploring paradigm continuity. Dev Chang. 2012;43(4):869-98.

Hamm P, King LP, Stuckler D. Mass privatization, state capacity, and economic growth in post-communist countries. Am Sociol Rev. 2012;77(2):295-324.

IMF. Rwanda-enhanced structural adjustment facility-second annual arrangement. Washington D.C; 1999.

IMF. Rwanda-poverty reduction and growth facility-three-year arrangement. Washington D.C.; 2002.

IMF. Capacity development. Washington D.C.: International Monetary Fund.; 2016.

IMF. IMF fiscal monitor: tackling inequality, world economic and financial surveys. Washington D.C.: International Monetary Fund; 2017a.

IMF. World economic outlook: seeking sustainable growth. In: World economic and financial surveys. Washington D.C.: International Monetary Fund; 2017b.

Di John J. The political economy of taxation and tax reform in developing countries. Helsinki: UNU-WIDER; 2006.

Keele L, Kelly NJ. Dynamic models for dynamic theories: the ins and outs of lagged dependent variables. Polit Anal. 2006;14(2):186-205.

Keen M. What do (and don't) we know about the value added tax? A review of Richard M. Bird and PierrePascal Gendron's "the VAT in developing and transitional countries". J Econ Lit. 2009;47:159-70.

Keen M, Lockwood B. Is the VAT a money machine? Natl Tax J. 2006;LIX(4):905-28.

Keen M, Lockwood B. The value added tax: its causes and consequences. J Dev Econ. 2010;92(2):138-51.

Kelley JG, Simmons BA. Politics by number: indicators as social pressure in international relations. Am J Polit Sci. 2015;59(1):55-70.

Kentikelenis AE, Babb SL. 'International Financial Institutions as Agents of Neoliberalism'. Pp. 16-27 in The SAGE Handbook of Neoliberalism, edited by D. Cahill, M. Cooper, M. Konings, and D. Primrose. Thousand Oaks: SAGE Publications. 2018.

Kentikelenis AE, Babb S. The making of neoliberal globalization: norm substitution and the politics of clandestine institutional change. Am J Sociol. 2019;124(6):1720-62.

Kentikelenis AE, Seabrooke L. The politics of the world polity: script-writing in intergovernmental organizations. Am Sociol Rev. 2017;82(5):1065-92.

Kentikelenis AE, Stubbs TH, King LP. IMF conditionality and development policy space, 1985-2014. Rev Int Polit Econ. 2016;23(4):543-82.

Lombardi D, Woods N. The politics of influence: an analysis of IMF surveillance. Rev Int Polit Econ. 2008;15(5):711-39.

Mabugu RE, Simbanegavi W. Tax and expenditure reforms in Africa: an overview. J Afr Econ. 2015;24(2): ii3-ii15. 
Mahon JE. Causes of tax reform in Latin America, 1977-95. Lat Am Res Rev. 2004;39(1):3-30.

Mankiw NG, Weinzierl M, Yagan D. Optimal taxation in theory and practice. J Econ Perspect. 2009;23(4): 147-74.

Mann M. The sources of social power: a history of power from the beginning to A.D. 1760. Cambridge: Cambridge University press; 1986.

Mansour M, Keen M (2009) Revenue mobilization in sub-Saharan Africa: challenges from globalization. IMF working paper 09/157. Washington D.C.

Mayer W, Mourmouras A. IMF conditionality: an approach based on the theory of special interest politics. Rev Int Organ. 2008;3(2):105-21.

Mirrlees J. Tax by design. Contemp Account Res. 2011;27(1):548-606.

Morrissey O, Prichard W, Torrance S (2014) Aid and taxation: exploring the relationship using new data. Available at: http:/www.ictd.ac/ju-download/2-working-papers/14-aid-and-taxation-exploring-therelationship-using-new-data (Accessed 1 June 2017).

Morrissey O, Torrance S. Aid and taxation. In: Handbook on the economics of foreign aid. Cheltenham: Edward Elgar; 2015. chapter 31.

Moser C, Sturm J-E. Explaining IMF lending decisions after the cold war. Rev Int Organ. 2011;6(3-4):30740.

Nickell SJ. Biases in dynamic models with fixed effects. Econometrica. 1981;49(6):1417-26.

Nooruddin I, Simmons JW. The politics of hard choices: IMF programs and government spending. Int Organ. 2006;60(4):1001-33.

Nooruddin I, Vreeland JR. The effect of IMF programs on public wages and salaries. In: Clapp J, Wilkinson R, editors. Global governance, poverty and inequality. London: Routledge; 2010. p. 90-115.

Ostry JD, Loungani P, Furceri D. Neoliberalism: oversold? Finan Dev. 2016;53(2):38-41.

Prichard W. Electoral competitiveness, political budget cycles and taxation in developing countries. ICTD Working Paper; 2014.

Prichard W. Reassessing tax and development research: a new dataset, new findings, and lessons for research. World Dev. 2016;80:48-60.

Prichard W, Cobham A, Goodall A (2014) The ICTD Government Revenue Dataset. ICTD working paper \#19.

Reinsberg B, Kentikelenis A, Stubbs T, King L. The world system and the hollowing out of state capacity: how structural adjustment programs affect bureaucratic quality in developing countries. Am J Sociol. 2019a;124(4):1222-57.

Reinsberg B, Stubbs T, Kentikelenis A, King L. Bad governance: How privatization increases corruption in the developing world. Regulation \& Governance. 2019b. https://doi.org/10.1111/rego.12265 (Online First).

Rickard SJ, Caraway TL. International demands for austerity: examining the impact of the IMF on the public sector. Rev Int Organ. 2018;14(1):35-57.

Roodman D. How to do xtabond2: an introduction to difference and system GMM in Stata. Stata J. 2009;9(1): 86-136.

Roodman D. Fitting fully observed recursive mixed-process models with cmp. Stata J. 2012;11(2):159-206.

Scheve K, Stasavage D. The conscription of wealth: mass warfare and the demand for progressive taxation. Int Organ. 2010;64(4):529-61.

Seabrooke L. Bitter pills to swallow: legitimacy gaps and social recognition of the IMF tax policy norm in East Asia. In: Park S, Vetterlein A, editors. Owning development: Cambridge University Press; 2010. p. 13760 .

Seabrooke L, Nilsson ER. Professional skills in international financial surveillance: assessing change in IMF policy teams. Governance. 2015;28(2):237-54.

Seelkopf L, Lierse H (2014) Tax introduction database (TID) codebook. https://doi.org/10.1080 /09692290.2015.1125937 (Accessed 1 December 2017).

Stewart F. Changing perspectives on inequality and development. Stud Comp Int Dev. 2016;51(1):60-80.

Stiglitz JE. Development-oriented tax policy. In: Pogge T, et al., editors. Initiative for policy dialogue working paper series. New York: Columbia University Press; 2009. p. 1-37.

Stone RW. Lending credibility: the International Monetary Fund and the post-communist transition. Princeton: Princeton University Press; 2002.

Stubbs TH, et al. The impact of IMF conditionality on government health expenditure: a cross-national analysis of 16 west African nations. Soc Sci Med. 2017a;174(3):220-7.

Stubbs T, Kentikelenis A, Stuckler D, McKee M, King L. The IMF and government health expenditure: A response to Sanjeev Gupta. Soc Sci Med. 2017b;181:202-204. 
Stubbs TH, Kentikelenis A. Conditionality and sovereign debt: an overview of human rights implications. In: Bantekas I, Lumina C, editors. Sovereign debt and human rights. Oxford: Oxford University Press; 2018a. p. 359-80.

Stubbs TH, Kentikelenis A. Targeted social safeguards in the age of universal social protection: the IMF and health systems of low-income countries. Crit Public Health. 2018b;28(2):132-9.

Stubbs TH, et al. How to evaluate the effects of IMF conditionality: an extension of quantitative approaches and an empirical application to government education expenditures. Rev Int Organ. 2020;15(1):29-73.

Swank D. The new political economy of taxation in the developing world. Rev Int Polit Econ. 2016;23(2): 185-207.

Tait AA. IMF advice on fiscal policy. International Monetary Fund: Washington D.C; 1989.

Tanzi V, Zee H. Tax policy for developing countries. Econ Issues. 2001;27.

Thacker SC. The high politics of IMF lending. World Polit. 1999;52(1):38-75.

Tilly C. European states, AD 990-1990. Cambridge and Oxford: Basil Blackwell; 1990.

Vernengo M, Ford K. Everything must change so that the IMF can remain the same: the world economic outlook and the global financial stability report. Dev Chang. 2014;45(5):1193-204.

Vreeland JR. The IMF and economic development. New York: Cambridge University Press; 2003.

Vreeland JR. The International Monetary Fund: politics of conditional lending. London: Routledge; 2007.

Wibbels E, Arce M. Globalization, taxation, and burden-shifting in Latin America. Int Organ. 2003;57(1): 111-36.

Woods N. The globalizers: the IMF, the World Bank, and their borrowers. Ithaca: Cornell University Press; 2006.

World Bank (2015) World development indicators. Available at: http://data.worldbank.org/. Accessed 1 Oct 2016.

Publisher's Note Springer Nature remains neutral with regard to jurisdictional claims in published maps and institutional affiliations.

Dr Bernhard Reinsberg is Lecturer in International Relations at the University of Glasgow and Research Associate in Political Economy at the Centre for Business Research at the University of Cambridge. He holds a $\mathrm{PhD}$ in Political Science from the University of Zurich, an MA in Comparative and International Studies at ETH Zurich, and BA degrees in Political Science (Freie Universität Berlin) and Mathematics (University in Hagen). His research focuses on the political economy of international development, with a particular emphasis on the role of international organizations. 